\title{
EXPERIMENTAL EVALUATION OF TWO SERPENTINE FLAT PLATE SOLAR WATER HEATING SYSTEMS
}

\author{
"Sameh, S. Kishk and ${ }^{* *}$ Mostafa A. Abu-Zeid
}

\begin{abstract}
The objective of this research work is to investigate the effect of changing working fluid mass flow rates and flow passage diameters on the thermal efficiency in the flat plate solar collector. Two identical flat plate solar collectors were designed, built and installed on the roof of the Agricultural Engineering Department, Faculty of Agriculture, Suez Canal University, Ismailia, Egypt (latitude of $30.62^{\circ}$, longitude $32.27^{\circ}$ and $5 \mathrm{~m}$ above sea level). The collector is rectangular in shape with surface area $1.5 \mathrm{~m}^{2}$. Aluminum sheet is used as an absorbing plate of $1 \mathrm{~mm}$ thickness. The diameter of serpentine copper tube was $6 \mathrm{~mm}$ (SC1) and $8 \mathrm{~mm}(\mathrm{SC2})$. A clear glass cover of $3 \mathrm{~mm}$ thick was placed to cover the solar collector. Insulated storage tank with 120 L was used to store the water after passed through the solar collector. The experiments were carried out at different mass water flow rates of $0.45,1.0$ and $1.75 \mathrm{~kg} \mathrm{~min}^{-1}$. The obtained results showed the SC2 increased the thermal efficiency by 19.3, 15.3 and $15.1 \%$ above that for the SC1 with flow rate $0.45,1.0$ and $1.7 \mathrm{~kg} \mathrm{~min}^{-1}$, respectively.
\end{abstract}

Keywords: Flat plate collector, solar energy, collector efficiency.

\section{INTRODUCTION}

7 he energy from the sun intercepted by the earth is many thousands of times larger than the present consumption rate on the earth of all commercial sources (Nandurkar and Shelke, 2012). One of the simplest and most direct applications of this energy is the conversion of solar radiation into heat. The solar collector is the key element in solar energy systems. It absorbs the solar radiation and converts it into a useable form of energy that can be applied to meet a specific demand (Grigorios, 2009).

*, " ${ }^{* *}$ Lecturer of Agric. Eng. Dep., Fac. of Agric., Suez Canal Univ., 41522 Ismailia, Egypt. 
Solar water heaters are devices that utilize solar radiation for a variety of purposes. Solar radiation is trapped by an absorbing medium and used for water heating. It is a technology that uses solar energy for water conditioning or heating in buildings or for different processes (Omajaro and Aldabbagh, 2010).

There are many advantages of solar water heater systems. They are simple to maintain and design. It is also an eco-friendly system which has zero greenhouse gas emissions (Maraba, 2012). Solar water heaters are simple device to heat water by utilizing solar energy and employed in many applications requiring low to moderate temperature below $60{ }^{\circ} \mathrm{C}$ (Forson et al., 2003; Kurtbas and Turgut, 2006). Duffie and Beckman (1991) performed annual simulation to monitor the thermal performance of a direct solar domestic hot water system. They found that the higher flow rate leads to higher collector efficiency factor. The thermal efficiency of the solar collector depends on how efficiently heat is transferred from the absorber to the flowing fluid (Pottler $\boldsymbol{e t}$ al., 1999). Kalogirou (2004) presented a useful review on solar thermal collectors. He showed that the temperature range for flat plate collectors was between $30-80^{\circ} \mathrm{C}$. Different collector configurations can help to obtain a large range of temperature for example, $20-80^{\circ} \mathrm{C}$ is the operating temperature range of a flat plate collector (Sharma and Diaz, 2011). Bolaji (2006) performed design and experimental analysis of flow inside the collector of a natural circulation solar water heater. The results showed the system performance depends very much on both the flow rate through the collector and the incident solar radiation. Performance of solar water heating system was studied by Sivakumar et al. (2012). The result records that the collector outlet temperature is the function of solar irradiance and time. The maximum collector efficiency during the day of experiment is obtained from using zig-zag arrangement. Efficiency according depends on the temperature of the plate, ambient temperature, solar insolation, top loss coefficient, emissivity of plate, transmittance of cover sheet, number of glass cover (Sekhar et al., 2009). Many studies have been devoted to modeling the performance of such collectors and examining their efficiency (Amrizal et al., 2013). Performance of collectors depends on the sole source of energy, namely 
the sun, and the main solar element of the climate is insolation, i.e. the time in which direct solar radiation reaches the surface of the earth. Flat plate solar collector type is the simplest form of solar water heater and can be constructed inexpensively. Flat plate collectors are the most common solar collector for solar water heating systems in homes and solar space heating. It consists of a dark surface called absorber, fluid flow passage and suitable provisions for heat loss reduction. The fluid flows in the tube which is bent in a zig-zag form called the serpentine form, which is the main source to the outlet of the collector. These collectors heat liquid or water at temperatures less than $80^{\circ} \mathrm{C}$. Solar water heating has been extensively studied and it has been reported that it can supply about $70 \%$ of sanitary water heating demand on residential and commercial facilities (Bracamonte $\boldsymbol{e t}$ al., 2015). Solar water heaters play a vital role in low temperature applications especially in domestic area (Patil, 2015). Flat Plate Solar Collector is one of the known devices developed for harnessing solar energy and converting it to heat, particularly for applications requiring energy delivery at moderate temperature of up to $100^{\circ} \mathrm{C}$ (Sukhatme and Nayak, 2008). Experimental analysis for two identical flat plate collectors with different tube spacing was studied by Fatigun $\boldsymbol{e t}$ al. (2012). They found that the tube spacing has a significant effect on the collector efficiency. Flat plate collector is a collector kind which operates in low-temperature levels up to $90{ }^{\circ} \mathrm{C}$ with an adequate thermal efficiency up to $70 \%$ (Bellos and Tzivanidis, 2018). Singh and Tiwari (2004) found that the solar radiation was maximized when the collector inclination is equal to the latitude of the place. The objective of this research work is to investigate the effect of changing working fluid mass flow rates and flow passage diameters on the thermal energy efficiency in the flat plate solar domestic water heating systems.

\section{MATERIALS AND METHODS}

Two identical flat plate glass solar collectors were designed, built and installed on the roof of the Agricultural Engineering Department, Faculty of Agriculture, Suez Canal University, Ismailia, Egypt (latitude of $30.62^{\circ}$, longitude $32.27^{\circ}$ and $5 \mathrm{~m}$ above sea level). Fig. (1) shows a picture of the 
two solar collectors. The collector is rectangular in shape and has five main components. A panel box, absorber plate, copper pipes, insulation materials and glass cover. Box made of wooden which enclosed the other collector components with dimensions of $160 \mathrm{~cm}$ long, $90 \mathrm{~cm}$ wide and $10 \mathrm{~cm}$ depth, respectively with surface area $1.5 \mathrm{~m}^{2}$. Aluminum sheet is used as an absorbing plate of $1 \mathrm{~mm}$ thickness which is a good conductor of heat. The absorber pipes which carry the water are the most important part of the solar collector. Water flows inside serpentine copper pipe flow only in one tube (zig-zag form). A copper pipe length was $26 \mathrm{~m}$ and consists of 30 channels with a pitch between tubes as $50 \mathrm{~mm}$ for each collector. The diameter of serpentine copper tube was $6 \mathrm{~mm}$ for the first collector (SC1) and $8 \mathrm{~mm}$ (SC2) for the other one. The absorber (plate and pipes) has painted in black to increase the absorption and to lower the emissivity of solar radiation. A clear glass cover of $3 \mathrm{~mm}$ thick was placed to cover the solar collector box to transmit the maximum possible of solar radiation flux incident on it. Glass cover has been sealed with silicon rubber which plays an important role between dissimilar materials.

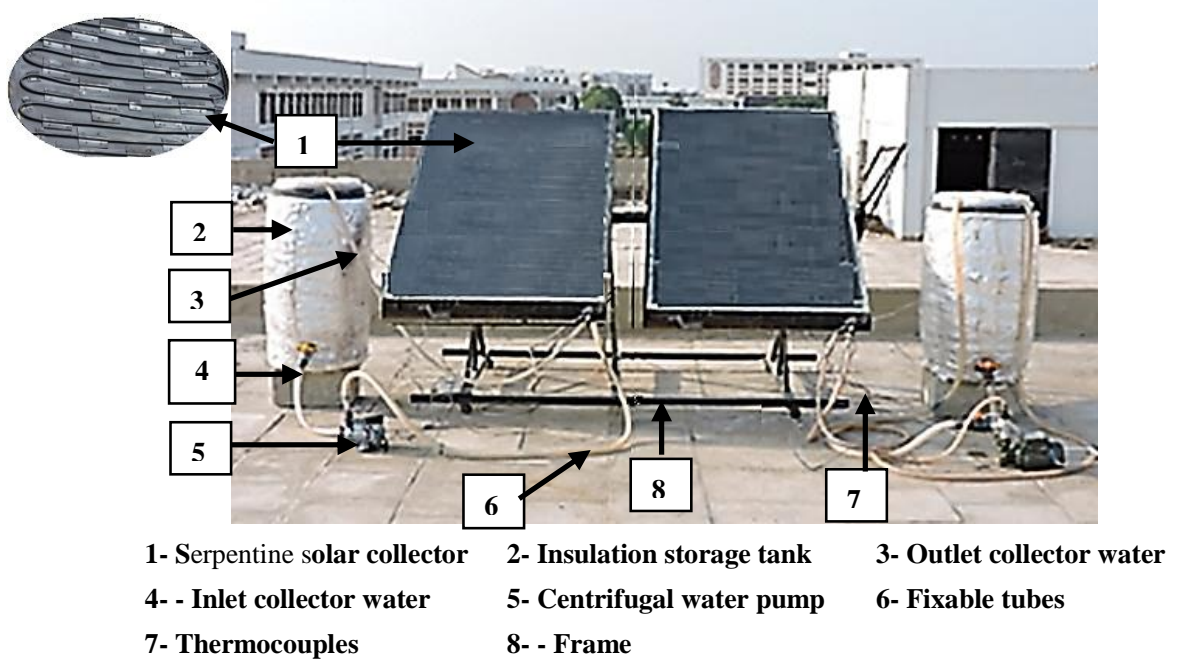

Fig. (1): A photo of two identical flat plate collectors integrated with storage tank

To minimize heat lose from the base and the sides of the collector box, the structure is good insulated with a Styrofoam material of $0.05 \mathrm{~m}$ thick (thermal conductivity $=0.04 \mathrm{Wm}^{-1} \mathrm{~K}^{-1}$ ) to prevent heat loss. Fixable polyethylene pipes with diameter of $2 \mathrm{~cm}$ were used to recirculate water 
between storage tank and solar collector again. Insulated storage tank was used to store the water after passed through the solar collector. Plastic storage tank with $120 \mathrm{~L}$ size made from plastic of $2 \mathrm{~mm}$ thickness and well insulated by a glass wool insulator of $0.05 \mathrm{~m}$ thickness. The solar collectors were positioned on a suitable steel structure and faced the south direction to maximize the intensity of the solar radiation to transmit the maximum possible of solar radiation flux incident on it. The solar collectors inclined at $31^{\circ}$ to maximize possible of solar radiation flux incident on it. The slope was adjusted to $31^{\circ}$, which is considered adequate for geographical location of Ismailia city. The water was continually cycled through the solar collectors using water centrifugal pump with a 375 Watt connected with storage tank. The experiments were carried out at different mass water flow rates $0.45,1.0$ and $1.75 \mathrm{~kg}$ $\mathrm{min}^{-1}$. The test was conducted from sunrise to sunset under clear sky conditions during August month of 2018. The experimental procedure commenced by cleaning dust from the external glass covers and the collected data was measured each hour during daylight. Meteorological station (Vantage Pro 2, Davis, USA) was used to measure different macroclimate variables such as solar radiation flux incident on a horizontal surface (pyranometer), dry-bulb and wet-bulb temperatures. Twelve calibrated thermocouples (Lab-Jack logger, powered by USB cable, supply 5 volt, USA) are used to measure the temperature at various points of water storage tanks, inlet and outlet water pipes of collectors. The output data were recorded every five minutes and averaged every one hour.

\section{Thermal efficiency of solar collectors}

Thermal efficiency of solar heating systems $(\boldsymbol{\eta})$ is defined as the ratio of useful energy gain $\left(\mathbf{Q}_{\mathbf{U}}\right)$ by the water to solar radiation incident on the absorber of solar collector Kurtbas and Turgut (2006)

$$
\eta=\frac{Q_{U}}{I . A}
$$

It is also known that the heat absorbed by the water (useful heat) is determined by the relationship:

$$
\mathrm{Q}_{\mathrm{u}}=\mathrm{mc}_{\mathrm{p}}\left(\mathrm{T}_{\mathrm{o}}-\mathrm{T}_{\mathrm{i}}\right), \quad[\mathrm{W}]
$$

Energy stored (Qs) by heating system: 


$$
\mathrm{Q}_{\mathrm{S}}=\mathrm{Mc}_{\mathrm{p}}\left(\mathrm{T}_{\mathrm{a}}-\mathrm{T}_{\mathrm{b}}\right), \quad[\mathrm{J}]
$$

Where:
A solar collector area $\left[\mathrm{m}^{2}\right]$
$\mathbf{C}_{\mathbf{p}}$ specific heat of water [4186 $\mathrm{J} \mathrm{Kg}^{-1} \mathrm{~K}^{-1}$ ]
I intensity of solar radiation $\left[\mathrm{Wm}^{-2}\right]$
M mass of water in storage tank $[\mathrm{kg}]$
m mass flow rate of water through the collector $\left[\mathrm{kg} \mathrm{s}^{-1}\right]$
$\mathbf{T}_{\mathbf{i}}, \mathbf{T}_{\mathbf{o}}$ inlet and outlet collector water temperature, respectively $\left[{ }^{\circ} \mathrm{C}\right]$
$\mathbf{T}_{\mathbf{a}}, \mathbf{T}_{\mathbf{b}}$ storage tank temperature at the end and the beginning of each day, respectively $\left[{ }^{\circ} \mathrm{C}\right]$

\section{RESULTS AND DISCUSSION}

Through all experimental works, the effects of solar collector tube diameter of $6 \mathrm{~mm}(\mathrm{SC} 1)$ and $8 \mathrm{~mm}(\mathrm{SC} 2)$ at different mass flow rate of $0.45,1.0$ and $1.7 \mathrm{~kg} \mathrm{~min}^{-1}$ were evaluated. The all measurements were taken during August month, 2018 and averaged every three days. The hourly variation of the solar intensity, ambient air temperature and collector water outlet temperatures are shown in Fig. (2). It can clearly be seen that, the solar radiation intensity and ambient air temperature gradually increased from sunrise until reaching the maximum value at noon, and then it gradually decreased until reaching the minimum value prior to sunset. From Fig. (2) the average of solar radiation and ambient air temperature for the investigation period were $\left(626 \mathrm{Wm}^{-2}\right.$ and $\left.29.5^{\circ} \mathrm{C}\right)$, $\left(543 \mathrm{Wm}^{-2}\right.$ and $\left.28.0^{\circ} \mathrm{C}\right)$ and $\left(690 \mathrm{Wm}^{-2}\right.$ and $\left.30.7^{\circ} \mathrm{C}\right)$ for solar collectors with mass flow rate $0.45,1.0$ and $1.7 \mathrm{~kg} \mathrm{~min}^{-1}$, respectively. The outlet water temperature depends on some parameters such as the intensity of the incident solar radiation, ambient air temperature, diameter of the copper tube and mass flow rate. As shown from the illustration, the highest outlet water temperature was obtained between 13:00 pm and 14:00 $\mathrm{h}$ for the all solar collectors. It is noticed that for the solar collectors with $0.45 \mathrm{~kg} \mathrm{~min}^{-1}$ mass flow rate the average outlet water temperature were found to be 57.2 and $61.9^{\circ} \mathrm{C}$, for $\mathrm{SC} 1$ and $\mathrm{SC} 2$, respectively. Similarly, the average outlet water temperature for the solar collectors with $1.0 \mathrm{~kg} \mathrm{~min}^{-1}$ mass flow rate was found to be 56.4 and $59.5{ }^{\circ} \mathrm{C}$, for $\mathrm{SC} 1$ and SC2, respectively. Meanwhile, the average outlet water temperature for the solar collectors with $1.7 \mathrm{~kg} \mathrm{~min}^{-1}$ mass flow rate was found to be 55.6 and $58.9^{\circ} \mathrm{C}$, for $\mathrm{SC} 1$ and $\mathrm{SC} 2$, respectively. From Fig. 
(2) it is found that the average outlet water temperature of the collector increases with the increase of the serpentine tube diameter and decreases with increase the mass flow rate. It is obvious that the maximum average outlet temperature is achieved at SC2 with $0.45 \mathrm{~kg} \mathrm{~min}^{-1}$ mass flow rate was found $61.9^{\circ} \mathrm{C}$.

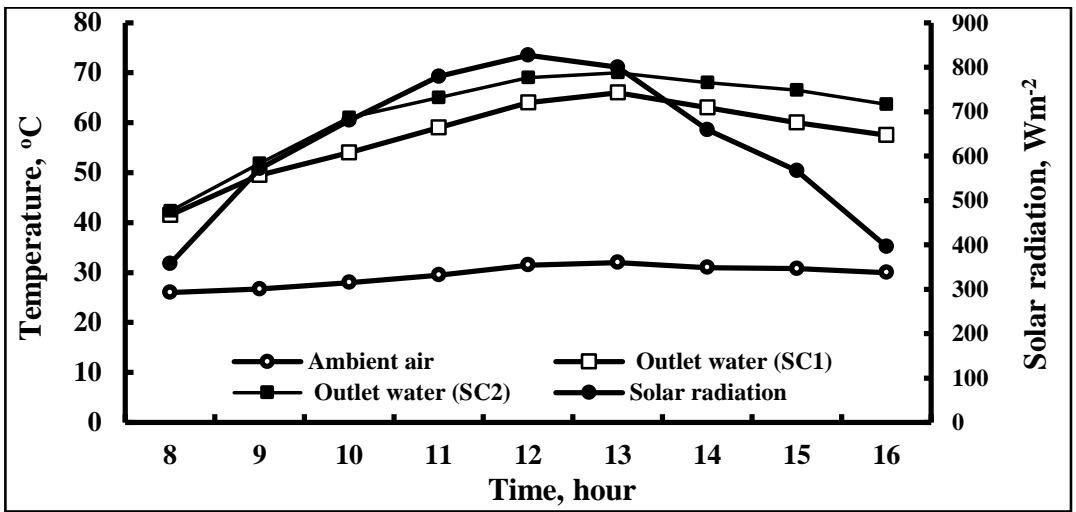

A - Solar collector with mass flow rate $0.45 \mathrm{~kg}$ min-1 (from $22^{\text {nd }}$ till $24^{\text {th }}$ August, 2018)

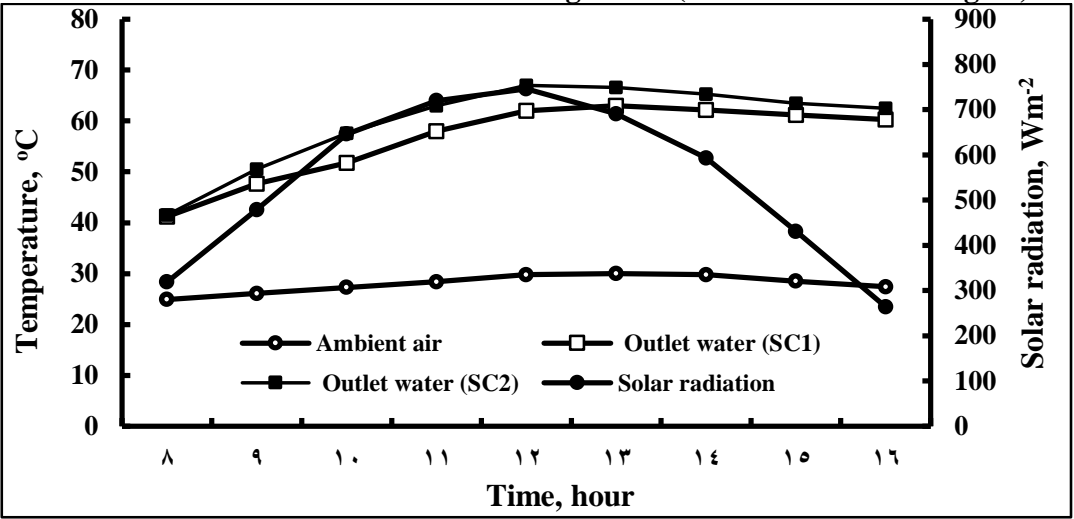

B - Solar collector with mass flow rate $1.0 \mathrm{~kg} \mathrm{~min}^{-1}$ (from $25^{\text {th }}$ till $27^{\text {th }}$ August, 2018)

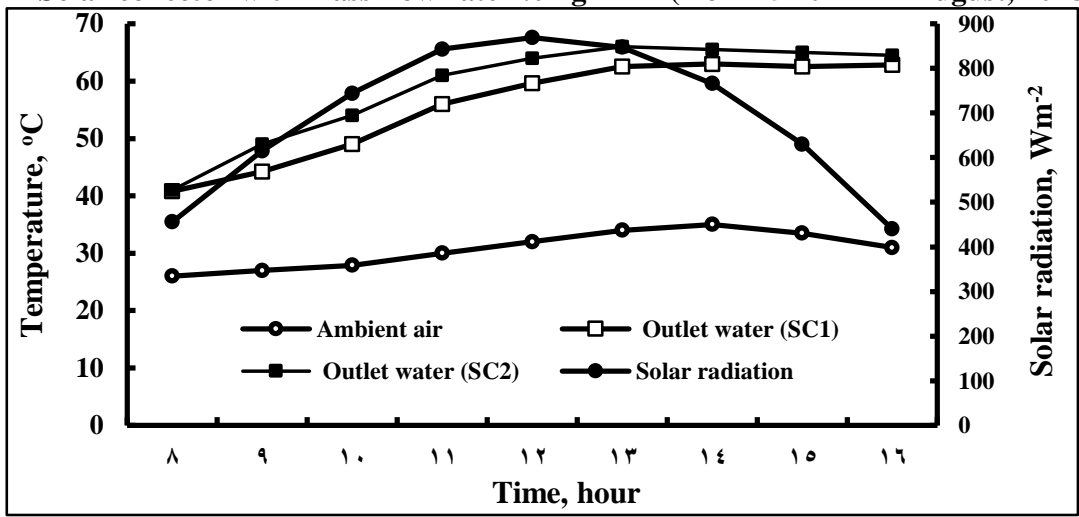

C - Solar collector with mass flow rate $1.7 \mathrm{~kg} \mathrm{~min}^{-1}$ (from $28^{\text {th }}$ till $30^{\text {th }}$ August, 2018)

Fig. (2): Variation of temperature and solar radiation with different mas flow rates 
Fig (3) depicts the temperature difference between the inlet and outlet water collector during an experimental procedure for the three different mass flow rates. It is obvious that the temperature differences increased in the morning hours and attain maximum values at local solar noon, and decreased in the evening hours. It is noticed that for the solar collectors with $0.45 \mathrm{~kg} \mathrm{~min}{ }^{-1}$ mass flow rate the average water temperature difference were found to be 9.4 and $11.0^{\circ} \mathrm{C}$, for $\mathrm{SC} 1$ and $\mathrm{SC} 2$, respectively. Also, the average difference for the solar collectors with $1.0 \mathrm{~kg} \mathrm{~min}-1$ mass flow rate was found to be 4.9 and $5.7^{\circ} \mathrm{C}$, for $\mathrm{SC} 1$ and $\mathrm{SC} 2$, respectively. Meanwhile, the average difference for the solar collectors with $1.7 \mathrm{~kg} \mathrm{~min}^{-1}$ mass flow rate was found to be 4.4 and 5.0 ${ }^{\circ} \mathrm{C}$, for $\mathrm{SC} 1$ and $\mathrm{SC} 2$, respectively. The temperature difference between inlet and outlet water collector is lower for higher mass flow rate, due to with higher water flow rate through the collector, the heat transferred per unit volume of water is lower and hence temperature difference between the inlet and outlet water decreases. These data are agreement with that published by Bolaji (2006). Fig (4) shows the variation of stored energy in storage tank produced from collector at different mass flow rates. The stored energy increases with increase mass flow rate and tube diameter. Solar collector SC2 with mass flow rate $1.75 \mathrm{~kg} \mathrm{~min}^{-1}$ gives the highest stored energy was 11.8 MJ. The reason is that the stored energy depends on the total circulating mass flow rate and collector outlet temperature. The most important part of this study was evaluating the thermal efficiency of the solar collector. Fig (5) shows the variations of thermal efficiency curves of the solar water collector at different mass flow rates under the average prevailing weather conditions. The thermal efficiency was low in the morning and afternoon because the solar intensity was low at that time. However, in the noon, the thermal efficiency was high because the temperature differences between inlet and outlet of the water were high.

For the duration of the experimental tests, the hourly average thermal efficiency was 29.4 and $35.1 \%$ for the SC1 and SC2, respectively at flow rate $0.45 \mathrm{~kg} \mathrm{~min}^{-1}$. Also, the average thermal efficiency for SC1 and SC2 was 39.3 and $45.3 \%$ respectively at $1.0 \mathrm{~kg} \mathrm{~min}^{-1}$. Meanwhile, the average thermal efficiency for the SC1 and SC2 was 48.5 and $55.8 \%$ with $1.7 \mathrm{~kg}$ $\min ^{-1}$ mass flow rate. 

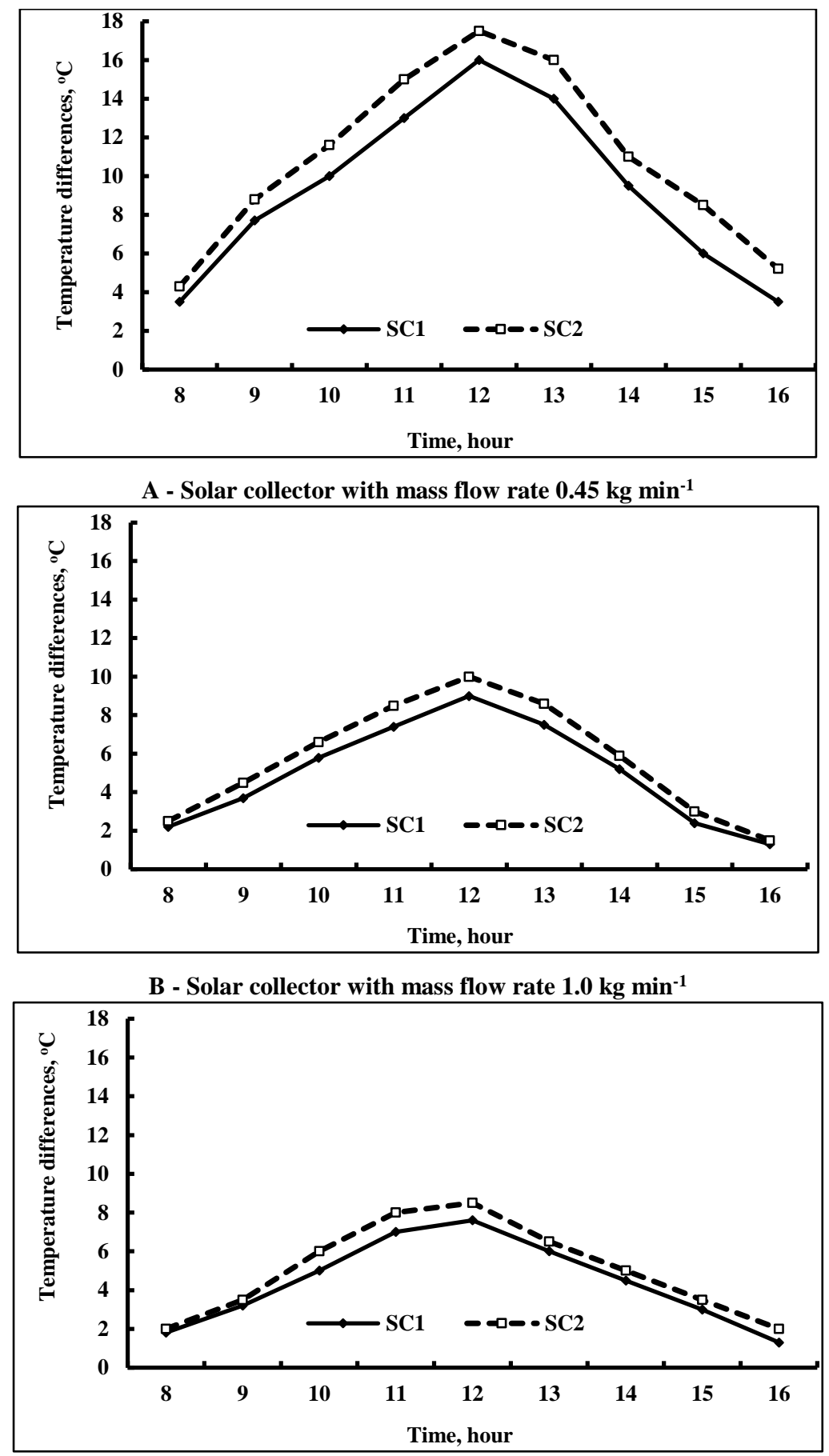

C - Solar collector with mass flow rate $1.7 \mathrm{~kg} \mathrm{~min}^{-1}$

Fig. (3): Hourly average temperature differences between inlet and outlet water collector as a function of solar time 


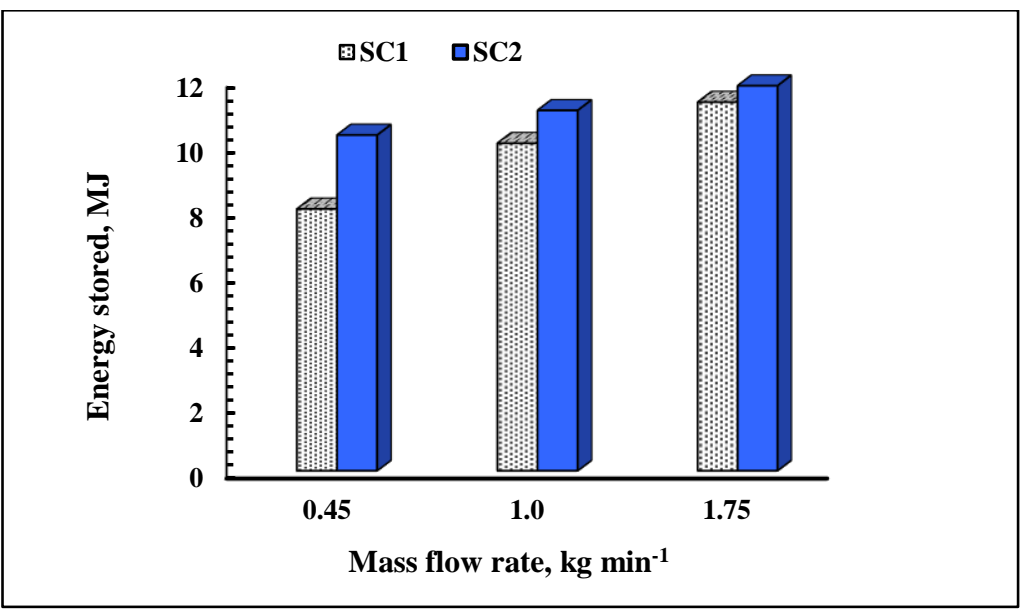

Fig. (4): Variation of stored energy with different mas flow rates

From Fig (5) the increasing in the water mass flow rate led to a considerable increase in the thermal efficiency of the collector. Also, it is found that the efficiency of the collector increases with the increase of the tube diameter. The graph reveals that the highest collector efficiency can be obtained at the tube diameter of $8 \mathrm{~mm}$ (SC2) and largest mass flow rate of $1.75 \mathrm{~kg} \mathrm{~min}^{-1}$. For instance, when the mass rate increased from 0.45 to $1.75 \mathrm{~kg} \mathrm{~min}^{-1}$, the average thermal efficiency increased from about 35.1 to about $55.8 \%$ for SC2. Similar results were reported by Alvarez et al. (2004). From Fig (5) it is found that the SC2 increased the thermal efficiency by $19.3,15.3$ and $15.1 \%$ above that for the SC1 with flow rate $0.45,1.0$ and $1.7 \mathrm{~kg} \mathrm{~min}^{-1}$, respectively.

\section{CONCLUSION}

In this present research work, several conclusions can be obtained and drawn as follows:

1- The average outlet water temperature of the collector increases with the increase of the tube diameter and decreases with increase the mass flow rate.

2- The maximum average outlet temperature is achieved at SC2 and $0.45 \mathrm{~kg} \mathrm{~min}{ }^{-1}$ mass flow rate was found $61.9^{\circ} \mathrm{C}$.

3- The temperature difference between inlet and outlet water collector is lower for higher mass flow rate. 

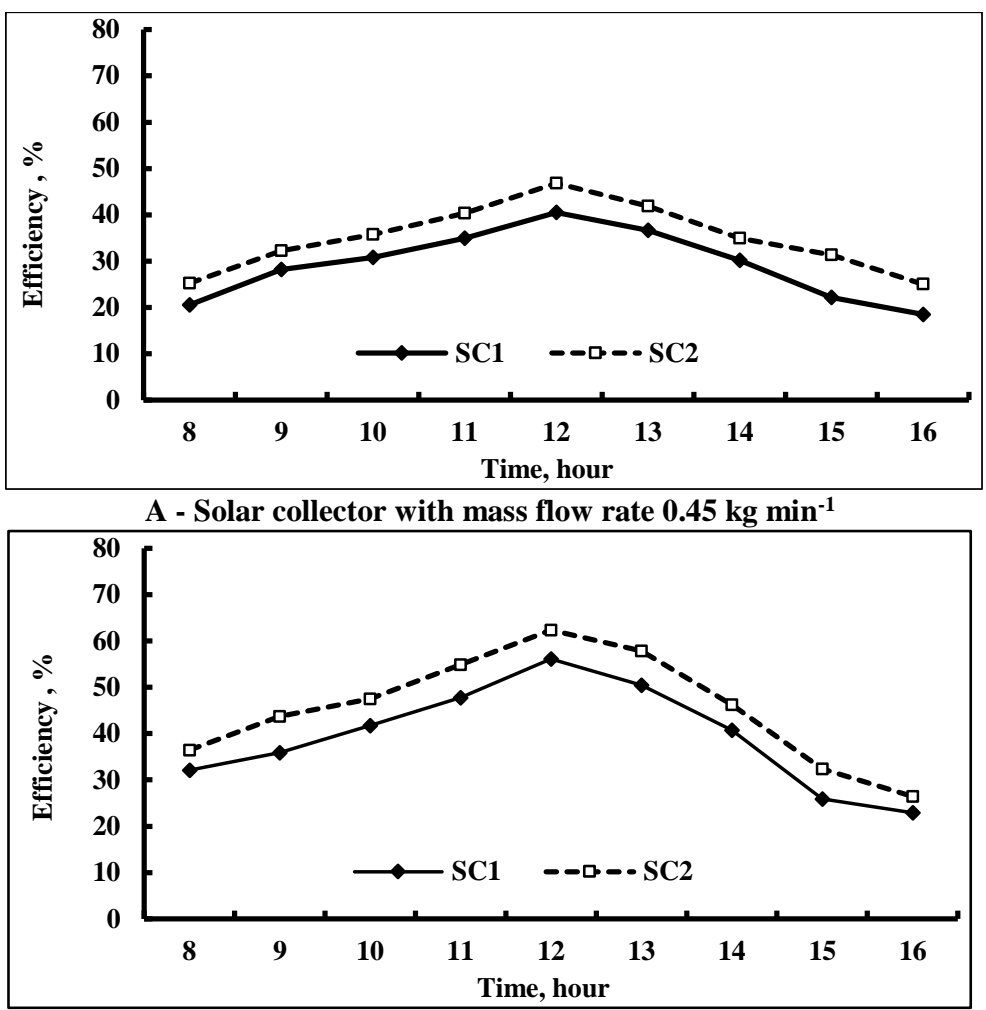

B - Solar collector with mass flow rate $1.0 \mathrm{~kg} \mathrm{~min}^{-1}$

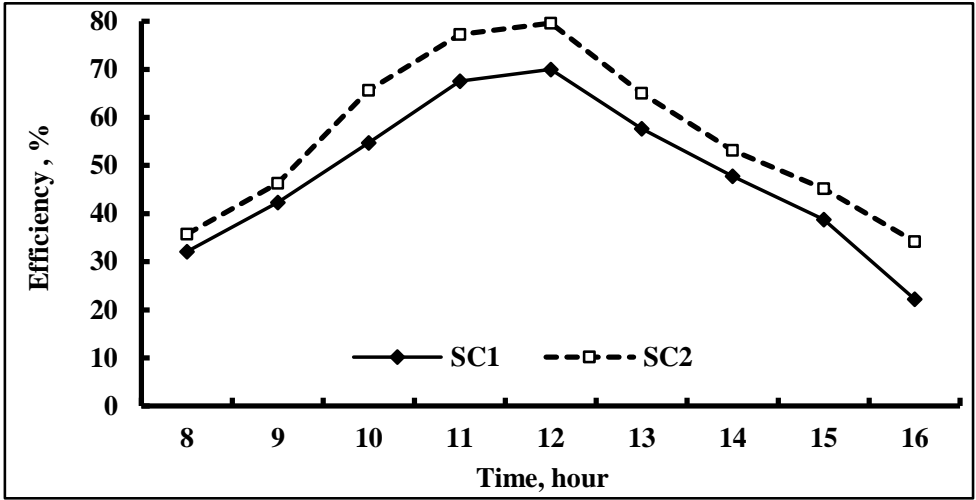

C - Solar collector with mass flow rate $1.7 \mathrm{~kg} \mathrm{~min}^{-1}$

Fig. (5): Thermal efficiency of solar collector at different water mass flow rates

4- Solar collector SC2 with mass flow rate $1.75 \mathrm{~kg} \mathrm{~min}^{-1}$ gives the highest stored energy was $11.8 \mathrm{MJ}$.

5- The efficiency of the collector increases with the increase of the tube diameter and mass flow rate. 
6- The SC2 increased the thermal efficiency by $19.3,15.3$ and $15.1 \%$ above that for the SC1 with flow rate $0.45,1.0$ and $1.7 \mathrm{~kg} \mathrm{~min}^{-1}$, respectively.

\section{REFERENCES}

Alvarez, G.; Arce, J.; Lira, L. and Heras, M. (2004): Thermal performance of an air solar collector with an absorber plate made of recyclable aluminum cans. Solar Energy, 77, 107-113.

Amrizal, N.; Chemisana, D.; and Rosell, J. I. (2013): Hybrid photovoltaic-thermal solar collectors dynamic modeling. Applied energy, 101, 797-807.

Bellos, E. and Tzivanidis, C. (2018): Development of an analytical model for the daily performance of solar thermal systems with experimental validation. Sustainable Energy Technologies and Assessments, 28, 22-29.

Bolaji, B. O. (2006): Flow design and collector performance of a natural circulation solar water heater. Journal of Engineering and Applied Sciences. 1(1), 7-13.

Bracamonte, J.; Parada, J.; Dimas, J. and Baritto, M. (2015): Effect of the collector tilt angle on thermal efficiency and stratification of passive water in glass evacuated tube solar water heater. Applied Energy, 155, 648 - 659.

Duffie, J. A. and Beckman, W. A. (1991): Solar Engineering of Thermal processes. 2nd (Edn.) John Wiley and Sons New York, USA. p. 488.

Fatigun, A. T., Adesakin, G. E. and Gwani, M. (2012): Experimental determination of the effect of tube spacing on the performance of a flat plate solar collector. International journal of environmental sciences, 3, (1) 363-370.

Forson, F. K., Nazha, M. A. A. and Rajakaruna, H. (2003): Experimental and simulation studies on a single pass, double duct solar heater, Energy conversion and Management, 44, 1209-1227.

Grigorios, I. (2009): Flat-Plate Solar Collectors for Water Heating with Improved Heat Transfer for Application in Climatic Conditions of the Mediterranean Region. $\mathrm{PhD}$ thesis, Durham University. Online: http://etheses.dur.ac.uk/174/ 
Kalogirou, S. A. (2004): Solar thermal collectors and applications, Progress in Energy and Combustion Science, 30 (3) 231-295.

Kramer, K. and Helmers, H. (2013): The interaction of standards and innovation: Hybrid photovoltaic thermal collectors. Solar Energy, 98 (C): 434 - 439.

Kurtbas, I. and Turgut, E. (2006): Experimental Investigation of Solar Air Heater with Free and Fixed Fins: Efficiency and Exergy Loss. International Journal of Science \& Technology, 1 (1) 75 - 82.

Maraba, G. (2012): An Experimental Study on Enhancement of Heat Transfer in a Solar Water Heater Collector by Using Porous Medium. M.Sc., School of Engineering and Sciences of Energy Engineering.

Nandurkar, Y. Y. and Shelke, R. S. (2012): Review of performance and analysis of Isi flat plate collector with modified flat plate collector. International Journal of Engineering Science and Technology (IJEST), 4 (3), 944-946.

Omajaro A. P. and Aldabbagh, L. B. Y. (2010): Experimental performance of single and double pass solar air heater with fins and steel wire mesh as absorber. Applied Energy, 87, 3759-3765.

Patil, P. P. (2015): A Review on Effect of Flat Plate Collector Design on Solar Water Heater Performance. International Journal of Science, Spirituality, Business and Technology (IJSSBT), 4, (1), 2277-7261.

Pottler, K.; Sippel, C. M.; Beck, A. and Fricke, J. (1999): Optimized finned absorber geometries for solar air heating collectors, Solar Energy, 67, 35-52.

Sekhar, Y. R.; Sharma, K. V. and Rao, M. B. (2009): Evaluation of heat loss coefficient in Solar Flat plate Collectors, ARPN Journal of Engineering and Applied Sciences, 4(5), 15-19.

Sharma, N. and Diaz, G. (2011): Performance model of a novel evacuated-tube solar collector based on mini channels. Solar Energy, 85, 881-890.

Singh, H. N.; and Tiwari, G. N. (2004): Monthly performance of passive and active solar stills for different Indian climatic conditions. Desalination, 168, 145 -150.

Sivakumar, P.; Christraj, W.; Sridharan, M. and Jayamalathi, N. (2012): Performance improvement study of solar Water heating 
system. ARPN Journal of Engineering and Applied Sciences, 7, (1), 45-49.

Sukhatme, S. P. and Nayak, J. K. (2008): Solar Energy; Principle of Thermal Collection and Storage, Third Edition. Tata McGraw-Hill Publishing Company Limited.

\section{الملخص العربى}

تقييم الكفاعة الحرارية لزوج من الأنظمة الشمسية المسطحة لتسخين الماء

\section{سامح سعيد كثُك ' و مصطفى عبد الراضى ابوزيد'}

أجري هذا البحث بقسم الهندسـة الزراعبـة ـ كلية الزر اعـة ـ جامعـة قناة السويس الإسماعيلية،

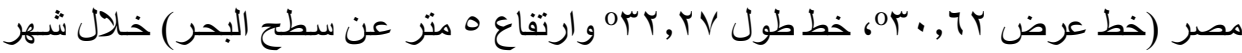

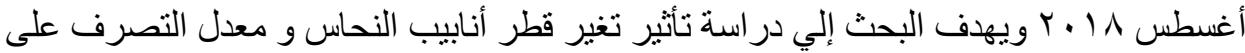

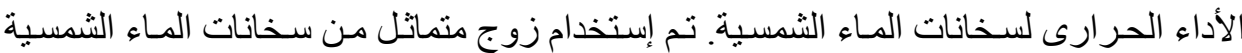

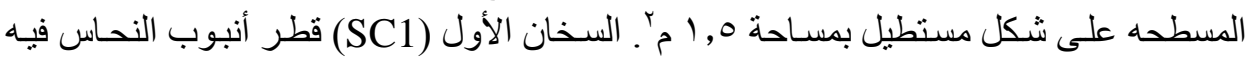

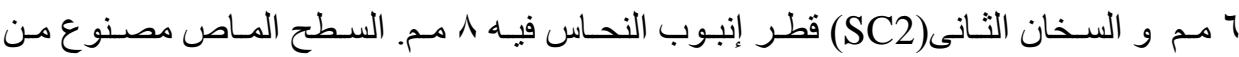

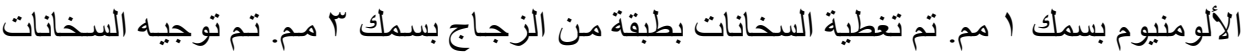

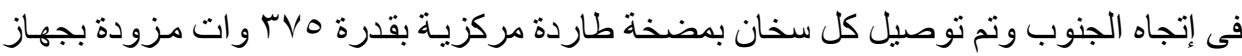

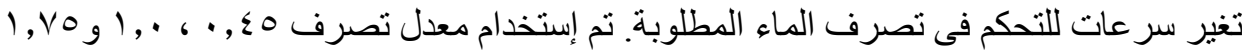

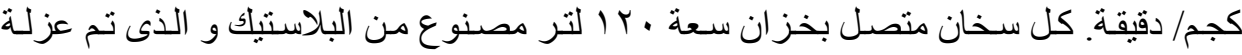

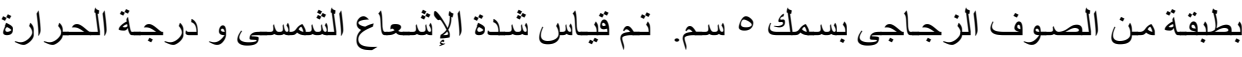
الداخلة و الخارجة من المجمع الثمسى.

$$
\text { وقد أوضحت النتائج مايلي: }
$$

متوسط درجة حرارة الماء الساخن الخارج من المجمع الثمسى يزداد مع زيادة قطر

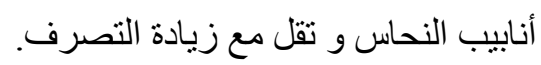

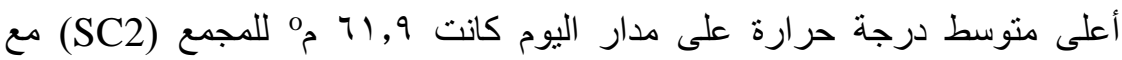

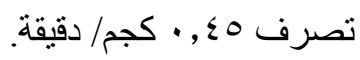

زيادة متوسط الفرق بين درجة حرارة دخول و خروة خروج الماء مع أقل تصرف.

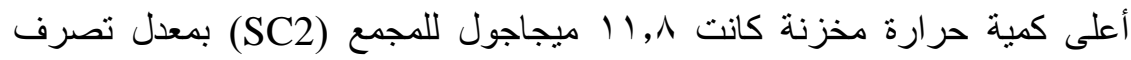

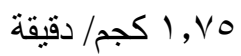

زيادة متوسط الكفاءة الحرارية الكلية للمجمع مع زيادة قطر الأنابيب و معدل التصرف.

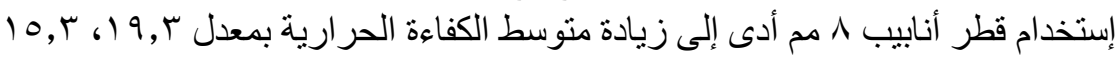

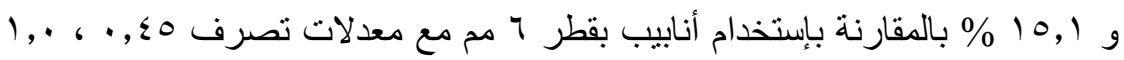

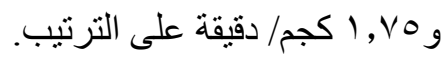

